\title{
On the Innovation Mechanism of University Library Resource Utilization --- A Case study of the China Three Gorges University
}

\author{
Ling Jiang ${ }^{1, a}$, Xiaohong Zhai ${ }^{2, b}$ \\ ${ }^{1}$ Department of Library China Three Gorges University Yichang, 443002, China \\ ${ }^{2}$ College of Electronic Engineering and new energy China Three Gorges University \\ Yichang, 443002, China \\ aemail: jiangling@jctgu.edu.cn, bemail: 331911229 @qq.com
}

Keywords: Library; Resource Utilization; Innovation Mechanism; China Three Gorges University

\begin{abstract}
University library takes an important role in education and research to drive higher education development and promote to accomplish its missions. We analyzed some common problems in the utilization of university library resources, including information supply, knowledge popularization and characteristic service based on close relationship between library resource utilization and university development and its great significance. Taking relevant experiences of libray at China Three Gorges University for example, this essay discussed the innovative method of utilizing university library resource, including setting up "the second classroom”, providing venture information, strengthening the training of resource supply, carrying on academic lectures etc. to promote the development of talent cultivation, scientific research and social services in university.
\end{abstract}

\section{Introduction}

Because university library acts as a database of information collection, classification and service, it plays a vital role in cultivating talents. Therefore, it is a key criteria to evaluate a university grade. Nowadays, there are some shortcomings in sharing library resources, such as unsuitable use, unclear function and ineffective service, which results that library resources can not meet demands of teachers and students, even more weakens university power. In this work, we analyzed the problem in utilizing library resources and tried to find some innovative methods to make full use of university library resources.

\section{Problems and new methods in utilizing university library resources}

Problem in utilizing university library resources mainly refers to incomplete information supply, which caused by lack of hardware facility, information quantity and work enthusiasm. Some factors limiting resourse share were stated as below.

From our questionnaire about library resource utilization in some universities, we found that just only $60 \%$ of students could regard library as their "second classroom" in their college period. Most of them only want to take a seat in this second classroom instead of acquiring wealth of knowledge held in this library reservoir containing a lot of books and journals. Therefore they got little knowledge from a library except a seat for their lesson review. In the other hand, it is ignored that the great aim of a library is to spread intelligence from the collected resources, which leads to waste library resources and weaken library function[1].

The low utilization rates of library resources in some universities were caused by the weak promulgation of their abundant resources. It was reported that over $80 \%$ interviewees did not know how to use databases such as China Knowledge Resource Integrated Database (CNKI, www.cnki.net). In some universities, some library resources are only offered to teachers and researchers, but not to the biggest community — students, which misleads students to feel that library resources are out of their reach. There is a broadening gap between students and library resources.

To most students, the key factor of making full use of library resources is appropriate guidance in improving search skills to get valuable information. At present situation, because some librarians 
lack work passion and service spirit, they would not like to spend more time to explain operating rules for readers to obtain more resources. Therefore, many resources were left behind in the library and did not reach the extensive utilization. Moreover, library resources were shelved if libraries cannot meet readers'demands. It twists the library function that going to library means to occupy a seat in it for reading books in stead of searching information from it. Sometimes, in the library of China Three Gorges University, we can hear noisy sound resulting from students' reading loudly, which broke the basic silence. Occasionally, there are some conflicts between librarians and students when persuaded not reading loudly in library. This confict phenomenon revealed that students did not really understand library original function. In other way, it's better to separate reading room and search rooms.

With the development of the times, readers' demands for library resources increase, which requires librarians to keep pace with this tendency to change work style of work and try their best to serve readers. However, some libraries still keep their traditional ways without any characteristics to offer information. Setting up more reading rooms could satisfy students, and improving method of resource supply could increase utilization efficiency and decrease the number of students entering library replaced by internet access out of library buildings.

After analyzed the present situation of resource utilization, we thought that it can not be ignored that the problems existed in some universities in utilizing library resources. In order to make full use of university library resources, it is urgent to carry out new methods to supply information and strengthen the internet web management. After internal management system reform recently, library of China Three Gorges University has improved the use of library resources and promoted the talent cultivation with innovative methods. And a high efficiency of resource utilization has been achieved.

In traditional concept, the function of university library is serving for teaching and scientific research[2]. However, with the coming of knowledge economy, challenge of information times and constructing of a learning society, university libraries must change their function to keep in pace with them. And their functions should be known by all students and teachers, as well as all potential individuals. Therefore, setting up "the second classrooms" is a way to make it sure that libraries are sources of intelligence for academic students, and also open-source of intelligence available for all people. This second classrooms will improve the library performance and speed up social progress [3].

Libraries provide many services, but traditionally, the most important service is lending books. In modern era, innovative educating derives from the top internet education sites-the best information is online not in books. Therefore, it is academic library's duty to collect creative and professional information from all over the world, and then offer them to students, which could combine library resources with students' professional demands. Students would be inspired by successful entrepreneurs displayed in professional database of academic library [4]. In recent years, China Three Gorges University has trained students to make their own business successfully due to better library service. Library also provides research information for students who took part in the "Challenge Cup" competition. Even more, some distinguished scholars were invited to give lectures in our library to discuss employment skill to help students get suitable professional position.

Library resources, seeming gold held in the earth, are waiting for people to explore. For most students, the training of library resource utilization is the key to open the door of the "treasure". On the other hand, the degree and quantity of utilizing knowledge is determined by the training background[3]. A good training method could maximize the utilization efficiency. In order to make full use of library resources, library of China Three Gorges University has made a training plan to improve utilization of library resources. The most important factor of this training project is to select skillful engineers to give lectures regularly on library resource utilization. Semesters on information search are held on every Friday, which has attracted over 5000 audiences. All these help students develop their search skills and good habits to use resources reasonably..

A university view determines its reputation. International popularity derives from internationalized talents coming from all over the world. Besides general education services, library 
of China Three Gorges University has broken the traditional routine and held academic lectures about methods of search the latest information from library. A lot of varied lectures satisfy the ever-growing needs of students. In other hand, the potential scholars are also trained in our university. Therefore, library of China Three Gorges University creates the first "college student forum" in China belonging to students completely, in which every student could give lecturer according to his/her mind to discuss library resource utilization. With the development of science and technology, versatile talents become more and more popular, while traditional unitary talents can not satisfy the social development only[6]. Library of China Three Gorges University has built up many special databases which reflects its characteristics, such as hydropower specialized reading rooms, resources of Wuling District, engineering immigration database, to provide information to those students who require common knowledge, as well as professional knowledge.

\section{Discussion}

A university library should be a resource reservoir, collecting a vast materials which can be borrowed or only referred within the Library premise and also can offer some rooms for learning and lectures. Users, who expect to utilize the resources in a library, need to know the types of materials from various collections, its location and its usage. As a information supplier, library should detail information of the materials available in the collection. Since the number of library users is increasing, library environment should be made more pleasant and comfortable. Therefore the detailed steps should be given out about how to get access to library collection.

A library classification is system of coding, assorting and organizing documents, library materials or any information

(books, serials, audiovisual materials, computer files, maps, manuscripts, realia) according to their subject and allocating a call number[clarification needed] to that information resource. This is known as a "mark and park" classification method, more formally called reader interest classification [7]. For examples, our library resources are classified according to General collection, Reference collection, Audio-visual materials, Serials collection (Current issues, Unbound issues and Bound issues), Special collection (Agricultural collection, Engineering collection, ect.), Bibliography collection, Newspaper collection, ect.

To service and provision of relevant materials for users this end, Professional, librarians continue to struggle to collect and organize printed and other forms of recorded knowledge in order to satisfy both present and future users.

But, many academic libraries are currently caught between pressures of increasing library usage and reduced budget. The rapid growth in student enrolments over the last few years has greatly increased the client group of academic libraries. The effectiveness of a library as an instrument of learning is determined by the success with which it is able to provide the user with the information he seeks. The library can fulfil its function best by pursuing a policy of constant self-evaluation in order to be alert to the changing needs of its users. The questions are that a library should know whether it is satisfactorily playing its role and how to make full of its resources [8].

New technology has changed the use of information and communication in 21st century. Libraries have transformed into digital and virtual libraries where books, journals, and magazines have changed into e-books, e-journals, and e-zines. Electronic resources are more easily accessible in remote areas. Even more previous printed resources are being digitized now. Electronic information sources are becoming more and more important for the academic community who rely on recent and timely information [9]. Electronic information resources is vast. The Library makes available a range of electronic information resources - these include e-journals, online databases and listings of useful weblinks. Librarians should select electronic resources to optimize value for their users. The roles of libraries as intermediates in the information delivery process may be changed substantially, and the delivery technology chosen effects who can use the material and for what purpose. Library may limit access by some patrons. Access control can help reasonable use by patrons traveling or working from home and using independent internet service providers [10]. Therefore accessing electronic information resources offers opportunities to obtain accurate and 
timely literature. High usage of electronic resources could increase the levels of workshops, seminars and communication. Students, not effectively using electronic information resources, will show low talent development.

\section{Conclusion}

A university library has its distinctive advantages in cultivating college students' creative ability. Library of China Three Gorges University has provided extensive information resources, improved the use of its resources and promoted the talent cultivation. University library could provide better services to teachers and students by reforming management system, and the utilization efficiency could increase to a great extent after implement these innovative method, which can help readers make full use of university library resources, and strengthen library function to serve the rapid developing world. It is an important matter to arouse full usage of library resources in a university, which should cause concern to both the university and library managers.

\section{References}

[1] Y.W. Deng and T.H. Wang, "Present Situation of and Responding Strategy Research on the Literature Resource Information Use for University Students,” Modern Information, 29, pp. 167-170, December 2009.

[2] C.K. Wang and Z.W. Ding, "Some Thinking on Quality Education for the College Students in the Second Classroom,” Journal of Guangxi Youth Leaders College, 11, pp. 45-46, February 2001.

[3] L. Deng, H.P. Liu, Q.Y. Zheng and C.X. Yu, “Growing the Practical Innovation Ability Combined with the Second Classroom,” China Electric Power Education, 246, pp. 12-14, June 2012.

[4] H.Q. Yue and Y.C. He, "Sufficient Use the Library Resource, Enhance the General Acknowledgement for the Students,” Popular Literature, 5, pp. 204 (5), May 2010.

[5] C.L. Zheng, " "Present Situation and Construction Approach of Campus Lecture," J. China Youth College for Political Sciences, 3, pp. 33-36, March 2006.

[6] C.L. Cheng, "Resource Allocation and Utilization Research of College Student Employment and Venture --- Basing on the Thinking on University Library,” Journal of West Anhui University, 28, pp. 154-156, April 2012.

[7] http://en.wikipedia.org/wiki/Library_classification.

[8] A. Ajayi and J.O. Adetayo, "Utilization of Library Books to Enhance Academic Excellence in Nigeria Tertiary Institution: A Case Study of Hezekiah Oluwasanmi Library, O. A. U., Ile-ife,” J. Soc. Sci., 10, pp. 119-122, 2005.

[9] A. M.Adegbore, “University Faculty Use of Electronic Resources: A Review of the Recent Literature,” http://unllib.unl.edu/LPP/PNLA\%20Quarterly/adegbore75-4.htm

[10] A. Gakibayo and C. Okello-Obura, "Electronic information resources utilization by students in Mbarara University library,” Library Philosophy and Practice, 2, pp. 1-26, 2013. 